\title{
SANKSI HUKUM TERHADAP PELAKU TINDAK PIDANA \\ PENYEROBOTAN TANAH
}

\author{
Oleh : \\ Kinaria Afriani,SH.,MH \\ Enni Merita , SH.,MH \\ (Dosen Tetap Sekolah Tinggi Ilmu Hukum Sumpah Pemuda Palembang)
}

\begin{abstract}
ABSTRAK
Tindak pidana penyerobotan tanah oleh seseorang atau sekelompok orang terhadap tanah milik orang lain dapat diartikan sebagai perbuatan menguasai, menduduki, atau mengambil alih tanah milik orang lain secara melawan hukum, melawan hak, atau melanggar peraturan hukum yang berlaku. Karena itu, perbuatan tersebut dapat digugat menurut hukum perdata ataupun dituntut menurut hukum pidana.

Adapun pasal-pasal dalam Kitab Undang-undang Hukum Pidana yang berkenaan dengan sanksi pidana terhadap tindak pidana penyerobotan tanah yaitu pasal 385 KUHP, yang terdapat pada buku ke II, bab XXV tentang kejahatan penipuan. Pasal 385 KUHP berbunyi; diancam dengan pidana penjara paling lama 4 (empat) tahun.Di samping KUHP pengaturan tindak pidana penyerobotan tanah diatur dalam Pasal 2 dan pasal 6 Peraturan Pemerintah Pengganti Undang-Undang Nomor 51 Tahun 1960 Tentang Larangan Pemakaian Tanah Tanpa Izin Yang Berhak Atau Kuasanya
\end{abstract}

Kata Kunci : Sanksi Hukum, Penyerobotan Tanah

\begin{abstract}
The criminal act of seizing land by a person or group of people against someone else's land can be interpreted as an act of controlling, occupying, or taking over someone else's land illegally, against rights, or violates applicable law. Therefore, the act can be sued according to civil law or prosecuted under criminal law.

The articles in the Criminal Law Act relating to criminal sanctions against the crime of land grabbing are article 385 of the Criminal Code, which is contained in book II, chapter XXV concerning fraud crime. Article 385 of the Criminal Code reads; threatened with imprisonment for a maximum of 4 (four) years. In addition to the Criminal Code the regulation of land seizure is regulated in Article 2 and Article 6 of the Government Regulation in Lieu of Law Number 51 of 1960 Concerning Prohibition of Use of Land Without a Rightful Permit or Proxy
\end{abstract}

Keywords: Legal Sanctions, Land grabbing

\section{A. Latar belakang}

Tanah merupakan sumber daya alam yang sangat dibutuhkan manusia, di mana kebutuhan manusia akan tanah selalu bertambah, dan ketersediaan akan tanah terbatas. 
Kebutuhan tanah tersebut baik dari segi ekonomi, sosial maupun segi teknologi. Tanah juga merupakan tempat dimana manusia hidup dan berkembang, serta sumber bagi kepentingan hidup manusia pada umumnya. Oleh karena terbatasnya tanah maka berdampak kepada nilai jual tanah yang semakin tinggi karena didasarkan pada semakin banyaknya permintaan atas tanah untuk pembuatan sarana umum, seperti : hotel, rumah sakit, dan rumah makan ataupun sarana pribadi seperti rumah, villa dan lain-lain.

Tanah dalam pengertian yuridis adalah permukaan bumi, hak atas tanah adalah hak atas sebagian tertentu dari permukaan bumi, yang terbatas, berdimensi dua dengan ukuran panjang dan lebar. ${ }^{1}$ Pengertian tanah menurut Pasal 4 ayat (1) UUPA adalah "permukaan bumi yang dapat diberikan kepada dan dipunyai oleh orang-orang baik sendiri maupun bersama-sama dengan orang lain serta badan hukum”. Pasal 4 ayat (2) UUPA menegaskan bahwa tanah- tanah yang dimaksud pada ayat (1) memberi wewenang untuk mempergunakan tanah yang bersangkutan sekedar diperlukan untuk kepentingan langsung berhubungan dengan penggunaan tanah alam batas-batas menurut UUPA dan peraturan yang lebih tinggi.

Tanah memiliki nilai yang dapat memberikan manfaat kepada manusia baik secara ekonomi, sosial dan politik. Bagi masyarakat Indonesia yang agraris,tanah adalah media utama untuk mencari sumber kehidupan. Begitu pentingnya tanah bagi kehidupan manusia sehingga setiap orang akan selalu berusaha memilikinya dan menguasainya.

Dalam masyarakat, perolehan tanah lebih sering dilakukan dengan peralihan hak. Pengertian peralihan hak atas tanah adalah perbuatan hukum yang sengaja dilakukan untuk mengalihkan hak atas tanah kepada orang lain yang menerima pengalihan. ${ }^{2}$

Perbuatan hukum itu dapat berupa :

a. Jual beli

b. Hibah dan Hibah wasiat

c. Tukar menukar

d. Pemisahan dan pembagian Harta bersama /warisan

e. Pemasukan harta / pokok kedalam Perseroan Terbatas (PT) - inbreng. ${ }^{3}$

Sedangkan menurut Peraturan Kepala Badan Pertanahan Nasional Republik Indonesia Nomor 1 Tahun 2010 Tentang Standar Pelayanan dan Pengaturan Pertanahan, peralihan hak atas tanah terdiri dari beberapa jenis, yaitu :

1 Effendi Perangin. Hukum Agraria Indonesia, Suatu Telaah Dari Sudut Pandang Praktisi Hukum.Raja Grafindo. Jakarta, 1994. Hlm 17.

2 R.Soeprapto, Undang-Undang Pokok Agraria Dalam Praktek,CV,Mitra Sari,Jakarta, 1986,hlm.221

3 John Salendeo, Masalah Tanah Dalam Pembangunan,Sinar Grafika, Jakarta, 1993, hlm.37 
a. Peralihan hak jual beli

b. Peralihan hak pewarisan

c. Peralihan hak tukar-menukar

d. Peralihan hak hibah

e. Peralihan hak hibah wasiat

f. Peralihan hak pembagian hak bersama.

g. Peralihan hak lelang

h. Pemasukan Dalam Perusahaan /Inbreng

Namun ada juga seseorang atau badan hukum yang ingin menguasai tanah tanah melalui peralihan hak yang sah namun dilakukan dengan penguasaan yang melawan hukum. Untuk menjamin kepastian hukum serta perlindungan hukum tersebut oleh pemerintah dalam kaitannya dengan peralihan hak atas tanah sebagaimana yang diamanatkan dalam ketentuan Pasal 19 ayat (1) Undang-Undang Nomor 5 Tahun 1960 tetang Pokok-Pokok Agraria atau yang lebih dikenal dengan UUPA diadakan pendaftaran tanah di seluruh wilayah Republik Indonesia menurut ketentuanketentuan yang diatur dengan peraturan pemerintah.

Penguasaan yang mantap berarti ditinjau dari aspek waktu atau lamanya seseorang dapat mempunyai atau menguasai tanah sesuai dengan isi kewenangan dari hak atas tanah tersebut, sedangkan penguasaan secara aman berarti si pemegang hak atas tanah dilindungi dari gangguan baik dari sesama warga negara dalam bentuk misalnya penguasaan illegal atau penyerobotan tanah.

Tindak pidana penyerobotan tanah sebenarnya bukanlah suatu istilah baru dalam hukum pidana tetapi mempakan istilah yang sama dengan kejahatan pada umumnya sebagaimana diatur dalam Buku Ke II KUHP, hanya saja kejahatan di bidang pertanahan ini berhubungan dengan tanah atau pertanahan sebagai objek atau salah satu unsur adanya kejahatan. ${ }^{4}$

Tindak pidana penyerobotan tanah oleh seseorang atau sekelompok orang terhadap tanah milik orang lain dapat diartikan sebagai perbuatan menguasai, menduduki, atau mengambil alih tanah milik orang lain secara melawan hukum, melawan hak, atau melanggar peraturan hukum yang berlaku. Karena itu, perbuatan tersebut dapat digugat menurut hukum perdata ataupun dituntut menurut hukum pidana. ${ }^{5}$

4 Muhadar, Viktimisasi Di Bidang Pertanahan, Laksbang Presindo, Yogyakarta, 2006,hlm. 46

5 Tri Andrisman, Asas-Asas dan Aturan Umum Hukum Pidana Indonesia, Universitas Lampung, Bandar Lampung, 2009, hlm. 70 


\section{B. Permasalahan}

Bertitik tolak dari uraian di atas, maka yang menjadi pokok permasalahan dalam penelitian ini dapat dirumuskan bagaimanakah sanksi hukum terhadap pelaku tindak pidana penyerobotan tanah

\section{Pembahasan}

Dalam suatu peraturan perundang-undangan, adanya pengaturan tentang sanksi atau hukuman pidana menjadi hal yang sangat penting karena di dalam hukum pidana kita dapat mengetahui perbuatan-perbuatan mana yang tidak boleh dilakukan, dilarang, dan harus dilakukan dengan disertai ancaman atau sanksi yang berupa pidana tertentu bagi barang siapa yang melanggar ketentuan tersebut. ${ }^{6}$

Tindak pidana penyerobotan tanah merupakan suatu perbuatan yang dilarang oleh hukum dan akan dikenakan sanksi bagi pelaku penyerobotan tanah tersebut. Tindak pidana penyerobotan tanah jika dilihat dari segi waktunya dibedakan menjadi dua, yaitu pada waktu perolehan dan pada waktu mengakui tanpa hak. Sehubungan dengan itu sekalipun seseorang disangka benar telah melakukan suatu tindak pidana penyerobotan tanah, akan tetapi hal itu bukan merupakan jaminan bahwa pelaku tersebut dapat dijatuhi hukuman, atau dengan kata lain tidak setiap orang yang melakukan kesalahan dapat dihukum sebelum benar-benar dinyatakan telah memenuhi segala syarat-syarat yang ditentukan dalam undang-undang. Atas dasar itulah P.A.F. Lamintang mengatakan bahwa orang pelaku tindak pidana adalah "Tidak cukup apabila disitu hanya terdapat suatu strafbaarfeit, melainkan harus juga strafbaar persoon atau seseorang yang dapat dihukum apabila strafbaarfeit yang dilakukan itu tidak bersifat wederchttelijk dan telah dilakukan baik dengan sengaja maupun dengan tidak sengaja". 7

Ada berbagai teori yang membahas alasan-alasan yang membenarkan (justification), penjatuhan hukuman (sanksi) dan dintaranya yaitu : teori absolut dan teori relatif.

1. Teori absolut,(vergeldingstheorie).

Menurut teori ini hukuman dijatuhkan sebagai pembalasan terhadap para pelaku karena telah melakukan kejahatan yang mengakibatkan kesengsaraan terhadap orang lain atau anggota masyarakat.

6 Djoki Prakoso, Pembaharuan Hukum Pidana di Indonesia, Liberty, Yogyakarta, 1987, hlm.. 19

7 P. A.F. Lamintang, Lamintang Theo, Delik-delik Khusus Kejahatan terhadap Harta Kekayaan, Sinar Grafika, Jakarta,2009, hlm. 174 
2. Teori Relatif (doeltheorie). Teori ini dilandasi oleh tujuan (doel)sebagai berikut :

a. Menyerahkan, dengan penjatuhan hukuman, diharapkan si pelaku atau terpidana menjadi jera dan tidak mengulangi lagi perbuatannya (speciale preventive)serta masyarakat umum mengetahui bahwa jika melakukan perbuatan sebagaimana dilakukan terpidana, mereka akan mengalami hukuman yang serupa (generale preventive).

3. b.Memperbaiki pribadi terpidana, berdasarkan perlakuan dan pendidikan yang diberikan selama menjalankan hukuman, terpidana merasa menyesal sehingga ia tidak akan mengulangi perbuatannya dan kembali kepada masyarakat sebagai orang yang baik dan berguna. ${ }^{8}$

Menurut Pasal 10 Kitab Undang-Undang Hukum Pidana. Pidana terdiri atas: 4.Pidana Pokok:

a. Pidana mati;

b. Pidana penjara;

c. Pidana kurungan;

d. Pidana denda;

e. Pidana tutupan.

2. Pidana Tambahan:

a. Pencabutan hak-hak tertentu;

b. Perampasan barang-barang tertentu;

c. Pengumuman putusan hakim.

Dalam tindak pidana penyerobotan tanah dibagi dalam tiga kategori berdasarkan waktu terjadinya perbuatan kejahatan tersebut, yaitu;

1. Pra-Perolehan

Pra-Perolehan; merupakan rangkaian perbuatan yang dilakukan sebelum diperoleh/didapatkannya suatu hak atas tanah. Pada kelompok tindak pidana ini, maka unsur utama dan penting untuk ditemukan adalah adanya perbuatan melanggar dan/atau menyalahi hukum yang dilakukan pelaku dalam upaya membuktikan adanya hubungan hukum antara pelaku dengan bidang tanah yang dikuasainya.

2. Menguasai Tanpa Hak

Menguasai Tanpa Hak; menggambarkan adanya hubungan hukum yang tidak sah antara pelaku dengan tanah yang dikuasainya. Ada penegasan kata "tanpa hak" 
dalam penguasaan tanah yang dilakukan pelaku, sehingga menunjukan adanya pihak lain yang memiliki hak atas tanah dimaksud.

\section{Mengakui Tanpa Hak}

Mengakui Tanpa Hak; bisa jadi secara fisik bidang tanah dimaksud belum dikuasai oleh pelaku, namun secara pengakuan, pelaku telah mengakui bahwa hanya dialah yang memiliki hak atas tanah tersebut sehingga memungkinkan pihak yang menguasai bidang tanah mengalami kerugian atas pengakuan pelaku tersebut. ${ }^{9}$

Adapun pasal-pasal dalam Kitab Undang-undang Hukum Pidana yang berkenaan dengan sanksi pidana terhadap tindak pidana penyerobotan tanah yaitu pasal 385 KUHP, yang terdapat pada buku ke II, bab XXV tentang kejahatan penipuan. Pasal 385 KUHP berbunyi; diancam dengan pidana penjara paling lama 4 (empat) tahun :

ke-1 barang siapa dengan maksud menguntungkan diri sendiri atau orang lain secara melawan hukum, menjual, menukarkan atau membebani dengan crediet verband sesuatu hak tanah Indonesia, sesuatu gedung, bangunan, penanaman atau pembenihan di atas tanah dengan hak Indonesia, padahal diketahui bahwa yang mempunyai atau turut mempunyai hak atasnya adalah orang lain ;

ke-2 barang siapa dengan maksud yang sama menjual, menukarkan atau membebani dengan crediet verband sesuatu hak tanah Indonesia yang telah dibebani crediet verband, atau sesuatu gedung, bangunan, penanaman atau pembenihan di atas tanah yang juga telah dibebani demikian, tanpa memberitahukan tentang adanya beban itu kepada pihak yang lain ;

ke-3 barang siapa dengan maksud yang sama mengadakan crediet verband mengenai sesuatu hak tanah Indonesia, dengan menyembunyikan kepada pihak lain, bahwa tanah yang berhubungan dengan hak tadi sudah digadaikan.

ke-4 barangsiapa dengan maksud yang sama, menggadaikan atau menyewakan tanah dengan hak Indonesia, padahal diketahui bahwa orang lain yang mempunyai atau turut mempunyai hak atas tanah itu

ke-5 barang siapa dengan maksud yang sama, menjual atau menukarkan tanah dengan hak Indonesia yang telah digadaikan, padahal tidak diberitahukan kepada pihak yang lain, bahwa tanah itu telah digadaikan. ke-6 barangsiapa dengan maksud yang sama,

9 Aloysius Mudjiyono dan Mahmud Kusuma, Penyidikan tindak pidana kasus tanah dan bangunan ,Pustaka Binaman Pressindo , Jakarta,2014, hlm.4 
menjual atau menukarkan tanah dengan hak Indonesia untuk suatu masa, padahal diketahui, bahwa tanah itu telah disewakan kepada orang lain untuk masa itu juga

Di samping KUHP pengaturan tindak pidana penyerobotan tanah diatur dalam Pasal 2 dan pasal 6 Peraturan Pemerintah Pengganti Undang-Undang Nomor 51 Tahun 1960 Tentang Larangan Pemakaian Tanah Tanpa Izin Yang Berhak Atau Kuasanya menyatakan bahwa :

Pasal 2 yang berbunyi : "Dilarang memakai tanah tanpa ijin yang berhak atau kuasanya yang sah".Unsur Pasal 2 ini adalah : -Memakai tanah tanpa ijin -Tanpa ijin yang berhak 2 .

Pasal 6 yang berbunyi :

a. Dengan tidak mengurangi berlakunya ketentuan dalam Pasal 3, 4 dan 5, maka dapat dipidana dengan hukuman kurungan selama-lamauya 3 (tiga) bulan dan/atau denda sebanyak-banyaknya Rp. 5.000,- (lima ribu rupiah);

1) Barang siapa memakai tanah tanpa ijin yang berhak atau kuasanya yang sah, dengan ketentuan, bahwa jika mengenai tanah perkebunan dan hutan dikecualikan mereka yang akan diselesaikan menurut Pasal 5 ayat 1;

2) barang siapa mengganggu yang berhak atau kuasanya yang sah didalam menggunakan haknya atas suatu bidang tanah;

3) Barang siapa menyuruh, mengajak, membujuk atau menganjurkan dengan lisan atau tulisan untuk melakukan perbuatan yang dimaksud dalam Pasal 2 atau sub b dari ayat 1 pasal ini

4) Barang siapa memberi bantuan dengan cara apapun juga untuk melakukan perbuatan tersebut pada pasal 2 atau huruf $b$ dari ayat 1 pasal ini;

b. Ketentuan-ketentuan mengenai penyelesaian yang diadakan oleh Menteri Agraria dan Penguasa Daerah sebagai yang dimaksud dalam pasal 3 dan 5 dapat memuat ancaman pidana dengan kurungan selama-lamanya 3 (tiga) bulan dan/atau denda sebanyakbanyakrrya Rp 5.000,- (lima ribu rupiah) terhadap siapa yang melanggar atau tidak memenuhnya.

c. Tindak pidana tersebut dalam pasal ini adalah pelanggaran.

Unsur Pasal 6 :

a) Barangsiapa

b) Memakai tanah tanpa ijin

c) Mengenai tanah perkebunan -haknya atas suatu bidang tanah

d) Memberi bantuan dengan cara apapun. 


\section{PENUTUP}

\section{Kesimpulan}

Adapun pasal-pasal dalam Kitab Undang-undang Hukum Pidana yang berkenaan dengan sanksi pidana terhadap tindak pidana penyerobotan tanah yaitu pasal 385 KUHP, yang terdapat pada buku ke II, bab XXV tentang kejahatan penipuan. Pasal 385 KUHP berbunyi; diancam dengan pidana penjara paling lama 4 (empat) tahun.

Di samping KUHP pengaturan tindak pidana penyerobotan tanah diatur dalam Pasal 2 dan pasal 6 Peraturan Pemerintah Pengganti Undang-Undang Nomor 51 Tahun 1960 Tentang Larangan Pemakaian Tanah Tanpa Izin Yang Berhak Atau Kuasanya

\section{Saran-Saran}

a. Agar tidak terjadinya tindak pidana pertanahan masyarakat seharusnya memiliki sertifikat hak (milik) atas tanah untuk memberikan kepastian hukum dan perlindungan hukum kepada pemegang hak atas suatu bidang tanah agar dengan mudah dapat membuktikan dirinya sebagai pemegang hak atas tanah yang bersangkutan.

b. Secara khusus perlu diadakan pengkajian ulang terhadap hierarki peraturan perundang- undang yang mengatur kewenangan Pemerintah Daerah di bidang pertanahan, agar pelaksanaan sistem pelayanan administrasi pertanahan di daerah menjadi lebih lancar, terarah dan terpadu secara efketif dan efisien.

\section{DAFTAR PUSTAKA}

Aloysius Mudjiyono dan Mahmud Kusuma, Penyidikan tindak pidana kasus tanah dan bangunan ,Pustaka Binaman Pressindo , Jakarta,2014

Djoki Prakoso, Pembaharuan Hukum Pidana di Indonesia, Liberty, Yogyakarta, 1987,

Effendi Perangin. Hukum Agraria Indonesia, Suatu Telaah Dari Sudut Pandang Praktisi Hukum.Raja Grafindo. Jakarta, 1994

John Salendeo, Masalah Tanah Dalam Pembangunan,Sinar Grafika, Jakarta, 1993

Leden Marpaung, Asas-Teori-Praktik Hukum Pidana, Sinar Grafika,Jakarta,2005,

Muhadar, Viktimisasi Di Bidang Pertanahan, Laksbang Presindo, Yogyakarta, 2006

P. A.F. Lamintang, Lamintang Theo, Delik-delik Khusus Kejahatan terhadap Harta Kekayaan, Sinar Grafika, Jakarta,2009

R.Soeprapto, Undang-Undang Pokok Agraria Dalam Praktek,CV,Mitra Sari,Jakarta, 1986

Tri Andrisman, Asas-Asas dan Aturan Umum Hukum Pidana Indonesia, Universitas Lampung, Bandar Lampung, 2009 